\title{
PENINGKATAN HASIL BELAJAR RANAH AFEKTIF MELALUI PEMBELAJARAN MODEL MOTIVASIONAL
}

\author{
Aryanti Nurhidayati \\ Prodi. Pend. Teknik Bangunan, Jurusan Pendidikan Teknik dan Kejuruan, FKIP, UNS \\ Kampus UNS Pabelan Jl. Ahmad Yani 200, Surakarta, Tlp/Fax 0271718419 \\ aryantinur@yahoo.com \\ Ernawati Sri Sunarsih \\ Prodi. Pend. Teknik Bangunan, Jurusan Pendidikan Teknik dan Kejuruan, FKIP, UNS \\ Kampus UNS Pabelan Jl. Ahmad Yani 200, Surakarta, Tlp/Fax 0271718419 \\ ernauns@yahoo.com
}

\begin{abstract}
ABSTRAK
Penelitian ini dilakukan untuk mengetahui pengaruh pembelajaran model motivasional terhadap peningkatan hasil belajar ranah afektif siswa.

Penelitian ini merupakan jenis penelitian eksperimental yaitu quasi experimental (eksperimental semu). Rancangan penelitian yang digunakan adalah Rancangan Pretest-Posttest Yang Tidak Ekuivalen (The Non Equivalent Pretest-Posttest Design). Sample penelitian ini adalah dua kelas mahasiswa yang mengambil mata kuliah Mekanika Tanah di Program Studi Pendidikan Teknik Bangunan, JPTK, FKIP, UNS. Satu kelas sebagai kelompok eksperimen dan satu kelas sebagai kelompok kontrol.

Hasil penelitian menunjukkan ada pengaruh pembelajaran model motivasional terhadap peningkatan hasil belajar ranah afektif siswa.
\end{abstract}

Kata kunci: pembelajaran model motivasional, penelitian eksperimental, hasil belajar ranah afektif

\section{PENDAHULUAN}

Hasil belajar merupakan hal yang tidak bisa dipisahkan dari kegiatan belajar mengajar atau proses pembelajaran. Penilaian terhadap hasil belajar dilakukan untuk mengukur tingkat kemajuan siswa dalam mengikuti kegiatan belajar mengajar. Menurut perspektif Bloom (1976), luaran hasil belajar siswa dikelompokkan menjadi 3 yaitu ranah kognitif, afektif dan psikomotor; dimana implikasinya yaitu evaluasi belajar siswa seharusnya meliputi ketiga ranah tersebut.

Kenyataannya, masih banyak pengukuran hasil belajarnya yang terfokus hanya pada ranah kognitif. Penilaian hasil belajar, cenderung mengesampingkan ranah afektif dan psikomotor siswa padahal ketiga ranah tersebut memberikan kontribusi yang sama pentingnya terhadap keberhasilan proses pembelajaran. Keberhasilan pembelajaran pada ranah kognitif dan psikomotor sangat ditentukan oleh kondisi afektif siswa (Suryanto, 2009). Siswa yang memiliki minat belajar dan sikap positif terhadap mata pelajaran akan merasa senang mempelajari mata pelajaran tersebut, sehingga siswa akan dapat mencapai hasil pembelajaran yang optimal. Saat ini banyak dijumpai siswa yang cerdas secara intelektual, tetapi mempunyai prestasi yang sedang-sedang saja bahkan rendah. Siswa dalam interaksi di kelas selama proses pembelajaran sering kelihatan bosan dan lesu, sedikit sekali menggunakan kemampuan terbaiknya untuk memecahkan permasalahan yang dikemukakan di kelas, apalagi secara aktif melibatkan diri dalam proses pembelajaran. Pada proses pembelajaran, apabila terdapat siswa yang tidak dapat berbuat sesuatu yang seharusnya dapat dilakukan, maka hal ini dapat diartikan bahwa pada diri anak tersebut tidak terjadi perubahan energi, tidak terangsang afeksinya untuk melakukan sesuatu karena tidak memiliki tujuan atau kebutuhan belajar (Sardiman, 1990). Keadaan semacam ini perlu dilakukan usaha atau upaya untuk menemukan sebab terjadinya masalah tersebut dan kemudian mendorong siswa untuk lebih dapat melakukan aktivitas yang seharusnya dilakukan dalam proses pembelajaran. Salah satunya siswa diberikan rangsangan agar motivasi di dalam dirinya tumbuh.

Penelitian ini bertujuan untuk mengetahui pengaruh pembelajaran model motivasional terhadap peningkatan hasil belajar ranah afektif siswa.

\section{LANDASAN TEORI \\ Hasil Belajar Ranah Afektif}

Ranah afektif merupakan segala sesuatu yang berkaitan dengan perasaan seorang individu. Seorang siswa yang tidak menunjukkan sikap dan minat yang positif terhadap suatu mata pelajaran tertentu akan sulit untuk mencapai 
prestasi yang optimum pada mata pelajaran tersebut.

\section{Level Ranah Afektif}

Krathwohl (dalam Gronlund dan Linn, 1990) menyatakan bahwa ranah afektif terdiri dari lima level, yaitu:

\section{Receiving}

Level ini mengindikasikan bahwa siswa memiliki keinginan untuk memperhatikan suatu stimulus yang muncul dalam proses pembelajaran, misalnya aktivitas di dalam kelas, buku, atau musik

\section{Responding}

Siswa pada level ini telah memiliki partisipasi aktif untuk merespon gejala yang sedang dipelajari di dalam kelas. Hasil pembelajaran pada level ini menekankan pada perolehan respon, keinginan memberi respon, atau kepuasan dalam memberi respon.

\section{Valuing}

Valuing merupakan kemampuan siswa untuk memberikan nilai, keyakinan, atau sikap dan menunjukkan derajat internalisasi dan komitmen. Hasil belajar pada level ini berhubungan dengan perilaku siswa yang konsisten dan stabil agar nilai dapat dikenal secara jelas.

\section{Organization}

Organization merupakan kemampuan siswa untuk mengorganisasi nilai yang satu dengan yang lain dan konflik antar nilai mampu diselesaikan dan siswa mulai membangun sistem nilai internal yang konsisten. Hasil belajar pada level ini berupa konseptualisasi nilai atau organisasi sistem nilai.

\section{Characterization}

Level ini merupakan level tertinggi ranah afektif, yaitu ketika siswa telah memiliki sistem nilai yang mampu mengendalikan perilakunya, sehingga menjadi pola hidupnya. Hasil belajar level ini berkaitan dengan personal, emosi, dan sosial.

\section{Cara Penilaian Ranah Afektif}

Penilaian ranah afektif dapat dilakukan dengan berbagai cara seperti penilaian yang dilakukan pada ranah kognitif dan psikomotor. Suryanto (2009) menyatakan ada lima cara yang dapat digunakan untuk melakukan penilaian pada ranah afektif, yaitu:

1. Observasi, yaitu dengan mencatat atau memperhatikan setiap perilaku siswa terhadap suatu stimulus yang ada dalam proses pembelajaran, misalnya buku, alat peraga, gambar, kejadian, dll.
2. Wawancara, yaitu dengan memberikan pertanyaan terbuka atau tertutup kepada siswa. Jawaban yang muncul dari siswa dapat dianalisis lebih lanjut untuk mengetahui keadaan afeksi siswa saat mengikuti proses pembelajaran.

3. Angket atau kuesioner, yaitu suatu perangkat pertanyaan atau pernyataan yang sudah disediakan pilihan jawabannya.

4. Teknik proyektil, yaitu memberikan tugas yang belum pernah dikenal oleh siswa. Siswa diminta untuk berdiskusi dan memberikan penafsiran terhadap tugas tersebut.

5. Pengukuran terselubung, merupakan pengamatan tentang sikap dan tingkah laku siswa dan siswa yang sedang diamati tidak mengetahui bahwa dirinya sedang diamati.

\section{Prinsip Pembelajaran Model Motivasional}

Motivasi merupakan hal yang penting dalam proses pembelajaran. Motivasi yang dimiliki oleh siswa akan menetukan keberhasilan siswa untuk mencapai prestasi yang memuaskan. Oleh karena itu, dalam proses pembelajaran, guru sebaiknya menerapkan prinsip-prinsip motivasi untuk menciptakan model pembelajaran yang merangsang, meningkatkan, dan memelihara motivasi siswa.

Model ARCS (Attention, Relevance, Confidence, Satisfaction), dikembangkan oleh Keller dan Kopp merupakan salah satu alternatif cara yang dapat dikembangkan oleh guru untuk merancang pembelajaran yang dapat mempengaruhi motivasi dan hasil belajar siswa. Keempat kondisi motivasional yang menurut Suciati dan Irawan (2005) adalah sebagai berikut: 1. Attention (Perhatian)

Perhatian siswa muncul didorong oleh rasa ingin tahu. Oleh sebab itu, rasa ingin tahu ini perlu mendapat rangsangan yang tepat, sehingga siswa akan dapat memberikan perhatian terhadap materi pelajaran yang disampaikan oleh guru dan perhatian tersebut akan dapat terpelihara dalam jangka waktu yang lama. Perhatian siswa dapat dirangsang dengan menggunakan media pembelajaran yang baru, aneh, atau media lain yang berbeda dari yang pernah ada.

2. Relevance (Relevansi)

Relevansi menunjukkan adanya hubungan antara materi pelajaran yang disampaikan di kelas dengan kebutuhan dan kondisi siswa. Motivasi siswa akan tetap terpelihara apabila siswa merasa bahwa materi yang dipelajari di kelas dapat memenuhi kebutuhannya atau bermanfaat bagi dirinya atau lingkungan di sekitarnya. 


\section{Confidence (Kepercayaan Diri)}

Motivasi siswa akan meningkat sejalan dengan meningkatnya harapan untuk berhasil. Harapan seringkali dipengaruhi oleh pengalaman sukses di masa lampau. Motivasi dapat menghasilkan ketekunan yang membawa prestasi dan selanjutnya pengalaman berprestasi tersebut akan memotivasi siswa untuk mengerjakan tugastugas berikutnya.

\section{Satisfaction (Kepuasan)}

Keberhasilan dalam mencapai tujuan akan menghasilkan kepuasan dan siswa akan termotivasi untuk terus berusaha mencapai tujuan serupa. Kepuasan yang diperoleh dipengaruhi oleh konsekuensi yang diterima. Motivasi siswa dapat dipelihara dan ditingkatkan dengan memberikan penguatan berupa pujian, pemberian kesempatan bertanya atau menjawab pertanyaan ketika di kelas.

Peningkatan Hasil Belajar Ranah Afektif Siswa Melalui Pembelajaran Model Motivasional Proses pembelajaran terjadi dengan adanya interaksi antara siswa dengan guru. Pembelajaran menurut Bransford, Brown, dan Cocking (2000) dapat berlangsung berbasis pada lingkungan (learner-centered environments), berbasis pengetahuan (knowledge-centered environments) dan berbasis penilaian (assessment-centered environments). Ketiga lingkungan pembelajaran ini saling terkait satu sama lain dalam proses pembelajaran. Pencapaian akhir pada setiap proses pembelajaran adalah penilaian terhadap hasil belajar siswa. Hasil belajar siswa terkait dengan pencapaian siswa terhadap tujuan pembelajaran.

Kemampuan afektif merupakan bagian dari hasil belajar siswa yang sangat penting karena keberhasilan proses pembelajaran pada ranah kognitif dan psikomotor siswa ditentukan oleh kondisi afektifnya. Kondisi afektif siswa yang dapat menciptakan situasi pembelajaran yang kondusif untuk mencapai hasil belajar yang optimal meliputi minat belajar siswa terhadap materi pelajaran dan sikap positif siswa terhadap mata pelajaran yang ditunjukkan dengan rasa senang mengikuti pelajaran dan antusias setiap mengikuti pelajaran.

Pembelajaran model motivasional menerapkan empat prinsip dalam proses pembelajaran yang biasa dikenal dengan model ARCS (Attention, Relevance, Confidence, Satisfaction). Prinsip ARCS tersebut dalam proses pembelajaran nantinya akan dijabarkan melalui tindakan-tindakan atau aktivitas di dalam kelas yang dirancang sendiri oleh guru untuk dapat meningkatkan minat dan sikap siswa terhadap materi pelajaran.

\section{METODE PENELITIAN \\ Populasi, Sample, dan Sampling}

\section{Populasi}

Populasi dalam penelitian ini adalah seluruh mahasiswa Pendidikan Teknik Bangunan, JPTK, FKIP, UNS.

\section{Sample}

Sample dalam penelitian ini adalah dua kelas mahasiswa yang mengambil mata kuliah Mekanika Tanah di PTB, JPTK, FKIP, UNS. Satu kelas sebagai kelompok eksperimen dan satu kelas sebagai kelompok kontrol.

\section{Sampling}

Sampling dilakukan dengan teknik nonrandom. Random hanya dilakukan untuk menentukan kelas yang akan dijadikan sebagai kelompok eksperimen dan kontrol.

\section{Teknik Pengumpulan Data}

Hasil belajar ranah afektif siswa diukur dengan menggunakan behavioural checklist untuk melihat perilaku siswa sampai level organization. Behavioural checklist dibuat sendiri oleh peneliti dengan validitas dan reliabilitas indikator-indikator perilaku yang digunakan dilakukan melalui review personal judgement.

\section{Jenis Penelitian}

Penelitian ini merupakan jenis penelitian eksperimental yaitu quasi experimental (eksperimental semu). Rancangan penelitian yang digunakan adalah Rancangan Pretest-Posttest Yang Tidak Ekuivalen (The Non Equivalent Pretest-Posttest Design). Perlakuan diberikan pada 2 kelas pada mata kuliah Mekanika Tanah dan diperkirakan mempunyai kondisi yang sama. Kedua kelas diberikan pretest untuk mengetahui keadaan awal siswa sebelum mendapat perlakuan, yaitu pemberian pembelajaran model motivasional. Kelas I sebagai kelompok kontrol hanya akan mendapat pretest dan posttest, sedangkan Kelas II akan mendapatkan pretest, perlakuan dan posttest.

\section{Analisis Data}

Penilaian ranah afektif siswa dilakukan dengan menggunakan behavioural checklist. Setiap indikator perilaku terdapat dua kemungkinan penilaian yaitu ya dan tidak. Ya diberi skor 1 dan tidak diberi skor 0 , untuk pernyataan positif serta kebalikannya untuk pernyataan negatif. Analisis data dilakukan dengan membandingkan antara skor hasil pre test dengan post test dan membandingkan antara 
kelompok/kelas

eksperimen

dengan

kelompok/kelas kontrol. Analisis data dilakukan dengan menggunakan bantuan SPSS.

\section{HASIL DAN PEMBAHASAN}

\section{Hasil Penelitian}

Deskripsi Subjek Penelitian

Penelitian dilaksanakan di Prodi

Pendidikan Teknik Bangunan Jurusan Pendidikan

Teknik dan Kejuruan, FKIP, UNS. Subjek penelitian adalah mahasiswa semester 2, angkatan 2012 yang mengambil mata kuliah Mekanika Tanah.

Uji Hipotesis dengan Teknik Analisis Varian Dua Jalur

Uji hipotesis digunakan teknik analisis varian dua jalur untuk mengetahui pengaruh pembelajaran dengan model motivasional terhadap peningkatan hasil belajar ranah afektif melalui uji perbedaan mean antar dua kelompok subjek. Kelompok subjek terbagi atas dua hal yaitu kelas dan kondisi. Kelas terdiri dari kelas eksperimen dan kelas kontrol. Kondisi dibagi menjadi dua kategori yaitu pre test dan post test. Hasil uji dapat dilihat pada Tabel 1.

Tabel 1. Hasil Uji Hipotesis dengan Teknik Analisis Varian Dua Jalur

Tests of Between-Subjects Effects

\begin{tabular}{|c|c|c|c|c|c|}
\hline Source & $\begin{array}{l}\text { Type III Sum } \\
\text { of Squares }\end{array}$ & df & Mean Square & $\mathrm{F}$ & Siq. \\
\hline Corrected Model & $218.024^{z}$ & 3 & 72.675 & 6.226 & .001 \\
\hline Intercept & 40500.653 & 1 & 40500.653 & $3.469 \mathrm{E} 3$ & .000 \\
\hline Kelas & 88.911 & 1 & 88.911 & 7.616 & .007 \\
\hline Kondisi & 118.073 & 1 & 118.073 & 10.115 & .002 \\
\hline Kelas * Kondisi & 11.040 & 1 & 11.040 & .946 & .333 \\
\hline Error & 1400.823 & 120 & 11.674 & & \\
\hline Total & 42119.500 & 124 & & & \\
\hline Corrected Total & 1618.847 & 123 & & & \\
\hline
\end{tabular}

Hasil pengujian menunjukkan ada perbedaan hasil belajar ranah afektif antara kelas kontrol dan kelas eksperimen. Kesimpulan tersebut diambil berdasarkan hasil nilai signifikansi pada kelas sebesar 0,007 $(\mathrm{p}<0,05)$ yang berarti signifikan. Nilai signifikansi pada kelompok kondisi menunjukkan angka sebesar $0,002(\mathrm{p}<0,05)$ yang berarti signifikan, sehingga dapat disimpulkan bahwa ada perbedaan hasil belajar ranah afektif sebelum dan sesudah perlakuan.

\section{Pembahasan}

Hasil belajar merupakan fungsi atau dampak dari kegiatan belajar mengajar atau proses pembelajaran. Penilaian terhadap hasil belajar dilakukan untuk mengukur tingkat kemajuan belajar mahasiswa dalam mengikuti kegiatan belajar mengajar.
Kemampuan afektif merupakan bagian dari hasil belajar mahasiswa yang sangat penting karena keberhasilan proses pembelajaran pada ranah kognitif dan psikomotor siswa ditentukan oleh kondisi afektifnya. Kondisi afektif mahasiswa dapat mempengaruhi situasi pembelajaran yang kondusif untuk mencapai hasil belajar yang optimal meliputi minat belajar mahasiswa terhadap mata kuliah selanjutnya pada materi pembelajaran dan sikap positif mahasiswa terhadap mata kuliah yang ditunjukkan dengan rasa senang mengikuti pelajaran dan antusias setiap mengikuti kegiatan pembelajaran.

Prinsip pembelajaran model motivasional meliputi empat hal, yaitu Attention, Relevance, Confidence, dan Satisfaction (ARCS). Pelaksanaan prinsip pembelajaran ARCS adalah bahwa dalam setiap penyampaian materi pokok dan/ atau sub materi, dosen selalu mengkaitkan teori dasar dengan aplikasinya serta hubungannya dengan teori dasar lain baik pada mata kuliah yang sama maupun mata kuliah lain, sehingga siswa lebih percaya diri dan merasakan kegunaan mata kuliah yang sedang dipelajari.

Proses pembelajaran pada kelas eksperimen tidak hanya digunakan metode ceramah, tetapi digunakan beberapa metode pembelajaran dalam penyampaian materi pembelajaran. Penggunaan metode pembelajaran yang berbeda-beda pada kelas eksperimen dimaksudkan untuk menimbulkan minat dan motivasi mahasiswa dalam mengikuti perkuliahan.

Proses pembelajaran model motivasional memberikan hasil belajar ranah afektif yang berbeda dibandingkan dengan pembelajaran model konvensional Pembelajaran model motivasional berhasil meningkatkan motivasi mahasiswa sehingga tumbuh minat mahasiswa untuk mengikuti perkuliahan/pembelajaran mata kuliah Mekanika Tanah yang berarti bahwa pembelajaran model motivasional berpengaruh terhadap peningkatan hasil belajar ranah afektif mahasiswa.

Minat mahasiswa yang tinggi akan berdampak pada keantusiasan mereka terhadap materi perkuliahan. Penerimaan (receiving) mahasiswa terhadap mata kuliah Mekanika Tanah ditandai dengan mahasiswa selalu hadir pada setiap perkuliahan, mahasiswa mengerjakan setiap tugas yang diberikan dosen dan memperhatikan setiap penjelasan dari dosen sebagai wujud bahwa para mahasiswa tumbuh minat belajarnya. 
Tingkatan capaian yang berikutnya adalah level responding. Indikator yang tampak untuk level ini ialah diperlihatkan pada mahasiswa selalu menjawab pertanyaan yang diberikan dosen ataupun pertanyaan yang disampaikan oleh teman dan mahasiswa berani bertanya apabila ada materi yang kurang/tidak jelas.

Level ranah afektif tingkat yang ketiga yaitu valuing. Indikator pencapaian level ini antara lain mahasiswa berani mengemukakan pendapat saat proses pembelajaran, mahasiswa mau mencari referensi sendiri selain referensi yang dirujuk oleh dosen, dan mahasiswa mau mempelajari kasus yang berhubungan dengan materi perkuliahan.

Level keempat ranah afektif yaitu organization. Indikator tercapainya level ini antara lain mahasiswa mengerjakan tugas tanpa adanya tekanan serta mengumpulkannya tepat waktu dan mahasiswa menghargai setiap pendapat yang disampaikan mahasiswa lain dalam diskusi maupun perkuliahan.

Berdasar observasi yang dilakukan selama proses pembelajaran yaitu terdapat perbedaan minat dan keaktifan mahasiswa. Perbedaan yang ditunjukkan yaitu mahasiswa pada kelas eksperimen cenderung lebih aktif mengemukakan pendapat, lebih aktif bertanya tentang kasus-kasus di lapangan dan mampu menunjukkan contoh kasus yang berhubungan dengan materi yang sedang dipelajari.

Berdasar wawancara dengan beberapa mahasiswa kelas eksperimen, mereka lebih senang, lebih puas dengan model pembelajaran yang diterapkan karena selalu ada contoh-contoh kasus nyata yang berhubungan dengan materi perkuliahan. Selain itu mereka menjadi lebih tahu hubungan atau keterkaitan materi yang disampaikan pada mata kuliah Mekanika Tanah dengan materi mata kuliah lain yang dipelajari di Prodi Pendidikan Teknik Bangunan.

Keberhasilan pelaksanaan pembelajaran model motivasional ini juga mengindikasikan keberhasilan pembelajaran dengan pendekatan SCL (Student Centered Learning). Mahasiswa lebih aktif dengan ditumbuhkannya motivasi dan minat mereka. Pengajar/dosen hanya berfungsi sebagai fasilitator dalam proses pembelajaran.

\section{KESIMPULAN DAN SARAN Kesimpulan}

Kesimpulan yang dapat diambil dari penelitian ini adalah:
1. ada pengaruh pembelajaran model motivasional terhadap peningkatan hasil belajar ranah afektif,

2. ranah afektif yang dapat ditingkatkan yaitu receiving, responding, valuing dan organization,

3. mahasiswa pada kelas yang mengalami perlakuan (kelas eksperimen) lebih aktif dibandingkan kelas yang tidak mengalami perlakuan (kelas kontrol).

Saran

Berdasarkan analisis dan pembahasan hasil temuan pada penelitian maka

1. perlu adanya penelitian tentang efektivitas penerapan pembelajaran model motivasional ARCS dalam peningkatan hasil belajar terutama ranah afektif,

2. pembelajaran model motivasional dapat diterapkan pada mata kuliah lain yang mempunyai karakteristik sama dengan mata kuliah Mekanika Tanah

\section{DAFTAR PUSTAKA}

Bransford, J.D., Brown, A.L., \& Cocking, R.R. (2000). How People Learn. Brain, Mind, Experience, and School. Washington D.C.: National Academy Press.

Gronlund, N.E. \& Linn, R.L. (1990). Measurement and Evaluation in Teaching. New York: MacMillan Publishing Company.

Hartono. (2008). SPSS 16.0 analisis data statistika dan penelitian. Yogyakarta: Pustaka Pelajar.

Morgan, C. (1986). Introduction to Psychology. New York: McGraw-Hill Book Co.

Sardiman, A.M. (1990). Interaksi dan Motivasi Belajar Mengajar. Jakarta: Rajawali Pers.

Suciati \& Irawan, P. (2005). Teori Belajar dan Motivasi. Modul PEKERTI. Jakarta: Pusat Antaruniversitas untuk Peningkatan dan Pengembangan Aktivitas Instruksional Direktorat Jenderal Pendidikan Tinggi Departemen Pendidikan Nasional.

Suryanto, A. (2009). Evaluasi Pembelajaran di $S D$. Jakarta: Universitas Terbuka.

Wlodkowski, R. (1985). Enhancing Adult Motivation to Learn. San Francisco: Jossey-Bass Publishers. 